\title{
Time temperature indicator film based on alginate and red beetroot (Beta vulgaris L.) extract: in vitro characterization
}

\author{
Esra Tekin, Işıl Barutçu Mazı, Hasan Türe
}

Ordu University, Ordu, Turkey

\section{Keywords:}

Time temperature indicator

Red beetroot

Betalain

Alginate

PVA

\section{Article history:}

Received 28.10.2019

Received in revised

form 16.12.2019

Accepted 30.06.2020

\section{Corresponding}

author:

Işıl Barutçu Mazı

E-mail:

ibarutcu@odu.edu.tr

DOI: $10.24263 / 2304-$

974X-2020-9-2-7

\section{Abstract}

Introduction. This study was aimed to develop and characterize a biodegradable time temperature indicator (TTI) film by incorporating red beetroot (Beta vulgaris L.) extract, which is rich in betalain pigments, into alginate $(\mathrm{A}) /$ polyvinyl alcohol (PVA) blend film.

Materials and methods. The alginate-PVA blends (APVA) were prepared by mixing the 1\% PVA and 3\% A solutions at different A:PVA (v/v) ratios (2:3, 1:1, 3:2). TTI films were obtained by addition of ascorbic acid and red beetroot extract to APVA blends and adjusting the $\mathrm{pH}$ to 9.5 by adding $2 \mathrm{M} \mathrm{NaOH}$. The films were produced by casting technique. The pure A, pure PVA, APVA and TTI films were characterized by using Fourier transform infrared (FT-IR) spectroscopy, thermogravimetric analysis (TGA), and scanning electron microscopy (SEM).The mechanical properties of the films were established through stress/strain tests. The CIE $\mathrm{L}^{*} \mathrm{a} * \mathrm{~b} *$ color parameters of TTI film were obtained during seven days of storage at $4,25,40$ and $60{ }^{\circ} \mathrm{C}$.

Results and discussion. Increasing the concentration of A provided an increase in elastic modulus, tensile strength and elongation at break (\%) of APVA and TTI films. TTI(3:2) film had better film flexibility compared to A, APVA, TTI(1:1) and TTI(2:3) films. The ratio of A to PVA in blend films did not create a significant effect on TGA thermograms. Higher A proportion in TTI films decreased the phase separation observed in SEM images. The intensity of $\mathrm{O}-\mathrm{H}$ stretching band clearly increased in TTI films compared to other films. TTI (3:2) film stored at $4{ }^{\circ} \mathrm{C}$ did not undergo color change for 7 days, whereas the color of TTI stored at higher temperatures changed gradually during storage depending on the storage temperature. The changes in $b^{*}$ parameters and hue angle values were more pronounced; and generally $b^{*}$ and hue angle values of the samples stored above $4{ }^{\circ} \mathrm{C}$ started to increase significantly beginning of the first day.

Conclusions. The developed TTI film has a potential to monitor the quality changes of the foods, which are improperly stored but normally must be refrigerated, through color changes. 


\section{Abbreviations}

A: Alginate

APVA: Alginate-PVA blend

E: Elasticity Modulus

EB: Elongation at Break

FT-IR: Fourier Transform Infrared Spectroscopy

G: Glycerol
PVA: Polyvinyl Alcohol

SEM: Scanning Electron Microscopy

TGA: Thermogravimetric Analysis

TS: Tensile Strength

TTI: Time Temperature Indicator

\section{Introduction}

Traditional food packaging materials provide protection from environmental influences, contribute to the extended shelf-life, encourage consumers to purchase the product and have convenience attributes such as ease of access, handling [1]. Extensive research has been carried out for the development of food packaging materials and many successful innovations have been implemented for meeting and exceeding customers' demands and expectations [2, 3]. Intelligent packaging which carries information by sensing environment is one of the most popular innovative packaging systems [4]. Intelligent packaging is a system which enhances food safety by informing consumer about quality of the packed food and has extra characteristics such as detection, sensation, recording, tracing and communication [5]. It is known that the shelf life of the food depends on the internal structure of food and outside factors including temperature, relative humidity and outside gas composition [6]. Temperature which designates kinetics of physical, chemical and microbial deterioration is an important environmental factor. Time temperature indicators (TTIs) that record and observe temperature effect on food quality from production to consumption, are an easy to use and an impressive intelligent packaging system [7]. TTIs that confirm consumers with color indicators representing food quality are generally part of the food package [8]. Commercial TTIs have variable working mechanisms based on some mechanical, chemical, enzymatic or microbiological processes [4, 7]. Pennanen et al. [9] stated that much work is still needed to enable TTIs to gain a wider acceptance by the consumers.

Natural pigments that assist tracking food quality with color change can be used in active or intelligent packaging systems as an indicator of food deterioration [10-13]. The employment of natural pigments in indicators is advantageous, since such indicators do not have chemical effect on the packaged food. A couple of studies showed that some natural pigments derived from plants have significant potential as being time temperature indicators in intelligent packaging systems [14-16]. Nofrida et al. [14] used natural dyes of erpa leaves (Aerva sanguinolenta) in the development of a TTI film and recorded that the color of film changed from red to yellow at less than one day at room temperature and in 2 hours at $40{ }^{\circ} \mathrm{C}$. Maciel et al. [16] developed a TTI system by coating a cardpaper with chitosan suspension containing anthocyanin pigment as color indicator. The color of this TTI system changed irreversibly from violet to yellow when exposed to temperatures ranging from 40 to $70{ }^{\circ} \mathrm{C}$ for 72 hours due to thermal degradation of anthocyanins. Betalains are also an important group of plant derived natural pigments. The color of betalains may change depending on temperature, $\mathrm{pH}$, oxygen, enzyme and light [17]. Red beetroot (Beta vulgaris L.) is the most important betalain source used to colorize foods [18]. As a result of thermal degradation, red color of pigment decreases, and finally brown pigment is formed [19].

Natural biopolymers have been used for the development of indicator films in intelligent packaging applications. In the literature there are several reports on polymer-based time temperature indicator films. Nofrida et al. [14] obtained a TTI film using chitosan-PVA 


\section{- Food Technology —}

blend. Maciel et al. [15] designed temperature indicator cardpaper films coated with chitosan polymer incorporated with anthocyanins. Pereira et al. [20] developed a time temperature indicator film based on PVA/chitosan. Although several natural polymers have been used to prepare smart packaging with several types of pigments, to date betanin containing alginatePVA films have not been studied. Alginate and PVA are interesting polymers for the development of intelligent packaging since the film formed by blending them has greater mechanical properties and better cost performance, besides allows the incorporation of substances with specific properties [21, 22].

The aim of this study was to develop a time temperature indicator film based on alginate, PVA and natural betalain pigments extracted from red beetroot. The films were evaluated for chemical structure, and their morphological, mechanical and thermal properties using FT-IR, SEM and TGA. Evaluation of TTI film as a color indicator was performed during seven days of storage at $4,25,40$ and $60{ }^{\circ} \mathrm{C}$.

\section{Materials and methods}

\section{Materials}

The fresh red beet (Beta vulgaris L.) plants were obtained from the local market (Ordu, Turkey) and stored at $4{ }^{\circ} \mathrm{C}$ until extraction. Sodium alginate and polyvinyl alcohol (PVA, $\mathrm{M}_{\mathrm{W}}=89,000-98,000,99+\%$ hydrolyzed), L-ascorbic acid and glycerol were purchased from Sigma-Aldrich (St. Louis, MO, USA), and other reagents were of analytical grade.

\section{Preparation of red beetroot extract}

Red beetroots (Beta vulgaris L.) were washed, hand-peeled and cut into small pieces. $100 \mathrm{~g}$ of the grinded beet root was homogenized in $900 \mathrm{ml}$ of distilled water at room temperature using a homogenizer. Then, it was filtered and centrifuged at $4000 \mathrm{rpm}$ for 10 minutes. The obtained solution was diluted with distilled water to obtain a solution volume of $1 \mathrm{~L}$. The preparation of indicator film solution was performed immediately after obtaining red beetroot extract.

\section{Preparation of the films}

$1 \%$ PVA solution was obtained by completely dissolving $1.01 \mathrm{~g}$ of PVA powder in 100 $\mathrm{ml}$ of distilled water on a magnetic stirrer at $80-85^{\circ} \mathrm{C}$. To prepare the $3 \%$ alginate (A) film solution, $3.1 \mathrm{~g}$ of alginate was dissolved in $100 \mathrm{ml}$ of distilled water under magnetic stirring at $70-75{ }^{\circ} \mathrm{C}$ [23]. The alginate-PVA blends (APVA) were prepared by mixing the $1 \%$ PVA and $3 \%$ A solutions in the proportions given in Table 1. PVA, a non-toxic and biodegradable synthetic polymer, was added in order to improve the mechanical features of the alginate film. To see the effect of glycerol as plasticizer, $1 \mathrm{ml}$ of glycerol was added to $100 \mathrm{ml}$ of each film forming solution as presented in Table 1. All film forming solutions were kept under stirring at 300rpm at room temperature for 24 hours to obtain homogenized solution. Time temperature indicator (TTI) film forming solutions were prepared with the addition of $1 \mathrm{ml}$ glycerol, $0.5 \mathrm{~g}$ ascorbic acid and $10 \mathrm{ml}$ of red beetroot extract to $100 \mathrm{ml}$ of the homogenized APVA solutions (Table 1). Then, the final $\mathrm{pH}$ of the TTI solutions were adjusted to $9.5 \mathrm{using}$ $2 \mathrm{M} \mathrm{NaOH}$. The casting technique was used for the preparation of films. The solutions (12 g) were spread evenly over Petri dishes ( $60 \mathrm{~mm}$ diameter) and dried in vacuum oven (50mbar, Memmert VO 500, Germany) at $50{ }^{\circ} \mathrm{C}$ for 3 hours. The dry films were peeled off from the surface of plate and used for the further analyses. 
Composition of the film forming solutions

\begin{tabular}{|l|c|c|c|}
\hline Films & $\begin{array}{c}\text { A (3\%) / PVA(1\%) } \\
\text { ratio (v/v) }\end{array}$ & Glycerol & $\begin{array}{c}\text { Ascorbic acid and } \\
\text { red beet root extract }\end{array}$ \\
\hline A & $1 / 0$ & - & - \\
\hline PVA & $0 / 1$ & - & - \\
\hline A-G & $1 / 0$ & + & - \\
\hline PVA-G & $0 / 1$ & + & - \\
\hline APVA(1:1) & $1 / 1$ & - & - \\
\hline APVA(3:2) & $3 / 2$ & - & - \\
\hline APVA(2:3) & $2 / 3$ & - & - \\
\hline APVA(1:1)-G & $1 / 1$ & + & - \\
\hline APVA(3:2)-G & $3 / 2$ & + & - \\
\hline APVA(2:3)-G & $2 / 3$ & + & - \\
\hline TTI(1:1) & $1 / 1$ & + & + \\
\hline TTI(3:2) & $3 / 2$ & + & + \\
\hline TTI(2:3) & $2 / 3$ & + & + \\
\hline
\end{tabular}

\section{Determination of mechanical properties}

The dried films were cut into strips (10mm x $50 \mathrm{~mm}$ ) and conditioned for 48 hours at 25 ${ }^{\circ} \mathrm{C}$ in a desiccator containing over-saturated solution of magnesium nitrate $(50 \%$ relative humidity) prior to measurement of mechanical properties [24]. The thickness of the film strips was measured at five random positions using a digital caliper (Alpha-tools, Mannheim, Germany; $0.001 \mathrm{~mm}$ sensitivity) and the average thickness was used for the tensile tests. The tensile test was performed using a texture analyzing instrument (Texture Analyzer TA.XT.plus (Stable Micro System, England) equipped with miniature tensile grips probe at room temperature. Test method ASTM D1708-10 was used to measure the tensile properties of the films [25]. The crosshead speed was $1 \mathrm{~mm} / \mathrm{s}$. Tensile strength (MPa) was calculated by dividing the maximum load at break by the cross-sectional area of the film. Percent elongation at break was determined by dividing the length extended at the moment of rupture by the initial length of the film strip and multiplying by 100 . Elasticity modulus $\left(\mathrm{N} / \mathrm{mm}^{2}\right)$ was also calculated from the slope of the initial linear region of the stress-strain curve. At least 6 specimens for each film type were tested.

\section{Thermogravimetric analysis (TGA)}

Thermogravimetric analyses (Labsys Evo, Setaram Instrumentation, Caluire, France) were carried out in nitrogen atmosphere with a sample mass of approximately $9 \mathrm{mg}$ at heating rate of $10{ }^{\circ} \mathrm{C} \mathrm{min}^{-1}$ in a temperature range of $20-800{ }^{\circ} \mathrm{C}$.

\section{Fourier transform infrared spectroscopy (FT-IR)}

Fourier-transform infrared (FT-IR) spectroscopy [51] was conducted by using IR Affinity-1 Spectrometer (Shimadzu Corporation, Kyoto, Japan) in the wave number range from 4000 to $600 \mathrm{~cm}^{-1}$ at $4.0 \mathrm{~cm}^{-1}$ resolution with 64 scans. Data analysis of each film was performed with Peak Fit (Version 4.12) program. For each replicate two measurements were taken. 


\section{Scanning electron microscopy (SEM)}

SEM analysis was performed to examine the microstructure of films. SEM analysis was carried out using JSM-6400 Electron Microscope (JEOL Ltd, Tokyo, Japan) equipped with NORAN System 6 X-ray Microanalysis System. Prior to examination, samples were sputter coated with gold-palladium to render them electrically conductive by using Sputter Coater Device (Polaron Range, East Sussex, England).

\section{Colorimetric characterization of TTI film}

The TTI (3:2) film was used in the color analysis since it had higher percent elongation at break compared to other TTI films. The TTI (3:2) films were conditioned at different temperatures $\left(4,25,40\right.$ and $\left.60^{\circ} \mathrm{C}\right)$ for seven days. The CIE L*a*b* color parameters of TTI (3:2) films were measured (Minolta Chromameter CR-400, Osaka, Japan) immediately after being dried and on each day during seven days of storage. Five readings at different locations of the films were measured to obtain a mean value. The hue angle values were calculated by using the following equations [26].

$$
\begin{gathered}
\text { Hue }=\arctan (b * / a *), \\
\text { Hue }=\arctan (b * / a *)+360,
\end{gathered}
$$

\section{Statistical analysis}

Data were expressed as means \pm standard deviations. Statistical analysis was performed using Minitab 17. Differences were considered to be significant at validity of $\alpha=0.95$.

\section{Results and discussion}

\section{Mechanical properties}

Elasticity modulus (E), tensile strength (TS) and the elongation at break (EB) of the films were determined from the typical curves obtained through the tensile tests and summarized in Table 2.

Alginate film had E of 3376.0, TS of $49.63 \mathrm{MPa}$ and EB of $4.72 \%$. High E and low EB values mean that pure alginate film tends to be brittle. These results are consistent with the findings of Çaykara and Demirci [21] and Russo et al. [23]. Çaykara and Demirci [21] determined the elongation at break value of pure alginate $(1 \% \mathrm{w} / \mathrm{v})$ as $6.5 \%$. The addition of PVA to the alginate increased the E by $0.2-13.6 \%$ and TS by $1.5-10.6$. It can be seen that the stretch ability of the alginate film did not develop with the addition of PVA at 1:1 and 3:2 alginate/ PVA ratios. However, addition of PVA at the highest level (APVA (2:3)) provided $23.9 \%$ increase in EB of alginate (A) film. Similarly, Russo et al. [23] reported that the addition of PVA to alginate in a ratio of 1:1 did not provide a noticeable increase in strain at break. Compared to pure PVA film, the APVA blend films had higher E, TS and lower EB values as expected. The addition of glycerol to A, PVA and APVA blend films provided remarkable effects on the mechanical properties of films. TS and E of the films decreased significantly while EB values increased. With addition of glycerol, EB values of A, PVA and APVA films increased 9.3, 2.1 and 8.1-11.4 times, respectively. The E and TS of APVA blend films decreased from 2918.20-3370.0 to 26.42-40.26 and from 50.39-54.91 to 1.943.08 , respectively while the EB values increased from $4.32-5.85 \%$ to $47.27-50.25 \%$. This indicates that addition of glycerol made films more ductile. The PVA-G film was the most stretchable film with EB of $223.35 \%$. Increase in the stretch ability of films with higher EB 
and lower TS values with the addition of plasticizers has been reported in previous studies evaluating the effect of plasticizers on mechanical properties of films [23, 27, 28]. Plasticizers promote the formation of hydrogen bonds between plasticizers and the polymeric material and weaken the intermolecular forces of attraction in polymer which reduces the tensile strength and improves the flexibility of film by increasing molecular mobility of polymers $[22,27,28]$.

Table 2

Elasticity modulus (E), tensile strength (TS) and the elongation at break (EB) for the films

\begin{tabular}{|l|c|c|c|}
\hline Films & $\begin{array}{c}\text { Elasticity modulus } \\
\left(\mathbf{N} / \mathbf{m m}^{\mathbf{2}}\right.\end{array}$ & $\begin{array}{c}\text { Tensile strength } \\
(\mathbf{M P a})\end{array}$ & $\begin{array}{c}\text { Elongation at break } \\
\mathbf{( \% )}\end{array}$ \\
\hline A & $3376.00 \pm 332.00$ & $49.63 \pm 2.92$ & $4.72 \pm 1.31$ \\
\hline PVA & $466.40 \pm 67.70$ & $22.97 \pm 3.00$ & $105.64 \pm 16.80$ \\
\hline A-G & $126.43 \pm 26.90$ & $12.55 \pm 1.51$ & $43.91 \pm 4.45$ \\
\hline PVA-G & $4.43 \pm 0.58$ & $4.31 \pm 0.50$ & $223.35 \pm 48.50$ \\
\hline APVA(2:3) & $2918.20 \pm 314.10$ & $50.39 \pm 4.93$ & $5.85 \pm 0.99$ \\
\hline APVA(1:1) & $3201.00 \pm 536.00$ & $54.91 \pm 0.28$ & $4.32 \pm 2.67$ \\
\hline APVA(3:2) & $3370.00 \pm 399.00$ & $53.93 \pm 10.53$ & $4.74 \pm 0.91$ \\
\hline APVA(2:3)-G & $26.42 \pm 4.45$ & $1.94 \pm 0.12$ & $47.27 \pm 3.22$ \\
\hline APVA(1:1)-G & $31.23 \pm 5.59$ & $2.24 \pm 0.28$ & $49.44 \pm 2.67$ \\
\hline APVA(3:2)-G & $40.26 \pm 6.42$ & $3.08 \pm 0.42$ & $50.25 \pm 2.52$ \\
\hline TTI(2:3) & $4.41 \pm 0.44$ & $0.71 \pm 0.01$ & $24.38 \pm 1.07$ \\
\hline TTI(1:1) & $6.45 \pm 0.33$ & $1.36 \pm 0.11$ & $30.32 \pm 3.10$ \\
\hline TTI(3:2) & $6.32 \pm 1.98$ & $1.57 \pm 0.10$ & $51.71 \pm 3.17$ \\
\hline
\end{tabular}

TTI films contain also ascorbic acid and red beet root extract unlike APVA-G films. With the addition of these components, the E of APVA-G films reduced by $79-86 \%$. In addition, when compared to APVA-G films, the tensile strength values of TTI films have also decreased. This suggests the emergence of some intermolecular interactions with the addition of ascorbic acid and beetroot extract. The EB values of APVA (2:3)-G and APVA(1:1)-G films decreased by $48.4 \%$ and $38.7 \%$ whereas the EB of APVA (2:3)-G film stayed nearly constant. For both APVA and TTI blend films, increasing concentration of alginate provided an increase in E, TS and EB values of the films. TTI (1:1) and TTI(3:2) films had 22.7-30.2\%, 50.0-54.8\% and 19.6-52.9\% higher E, TS and EB values compared to TTI(2:3) film. This means that the higher alginate proportion improved the handling properties of TTI film. The TTI(3:2) film had better film flexibility compared to all other films except PVA film with or without glycerol.

\section{Thermogravimetric analysis}

The TGA curves of pure A and PVA and the blends were shown in Figures 1 and 2. The initial, final degradation temperatures and mass loss $(\%)$ were determined from TGA and DTG (differential gravimetric analysis) curves. The recorded thermogravimetric plots for all samples showed three mass loss regions. The first mass loss which begin around $26-28{ }^{\circ} \mathrm{C}$ was 13 and $26 \%$ for PVA and A, respectively. The first loss is ascribed to the removal of 
adsorbed water from the polymer matrix [29, 30]. Some authors also stated that the initial mass loss of PVA may also be associated with the splitting or volatilization of small molecules [31, 32]. Higher percent of mass loss of A may be related with the alginate's ability to retain high amounts of water. Comparing to pure A and PVA, initial decomposition temperature of APVA and TTI blends started at higher temperatures $\left(41-45^{\circ} \mathrm{C}\right)$ and the mass loss of blends ranged between $22-25 \%$ which were close to that of pure A. There was no clear difference between the blend films.

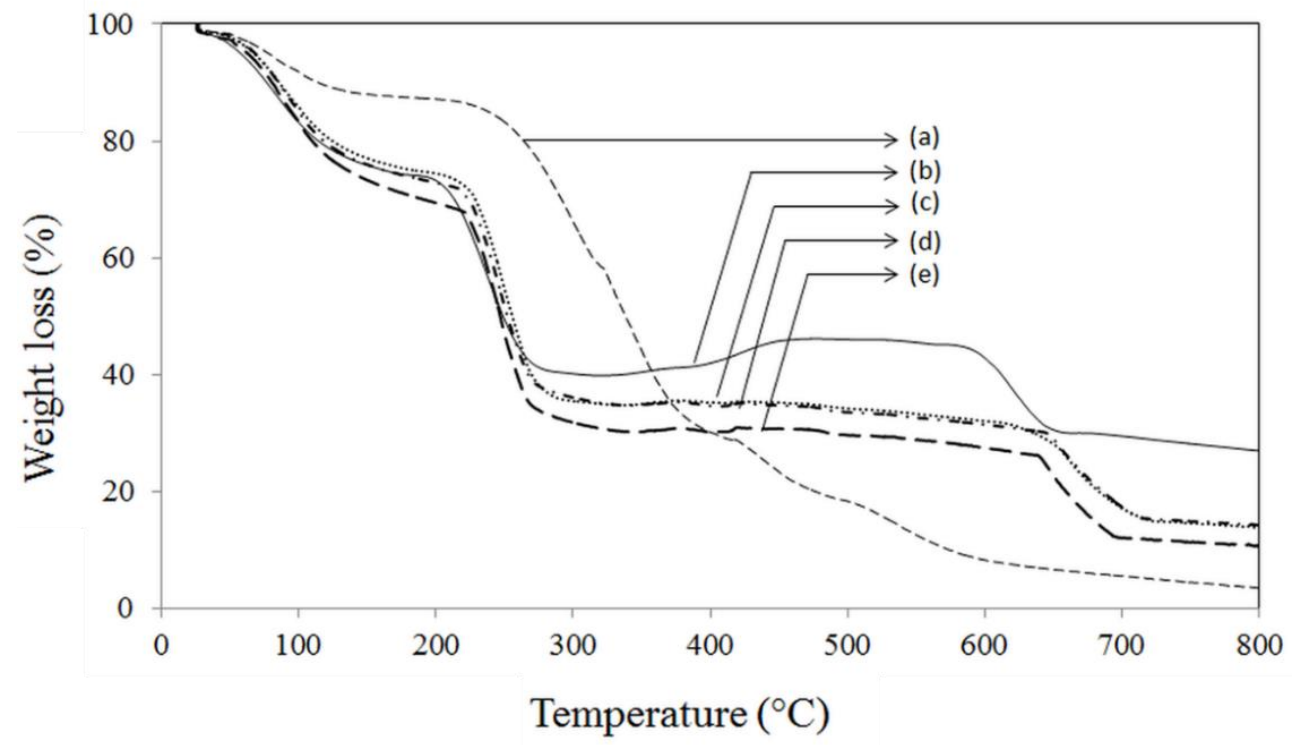

Figure 1. The TGA thermograms of PVA (a), A (b), $\operatorname{APVA}(1: 1)(c), \operatorname{APVA}(2: 3)(d)$ and $\operatorname{APVA}(3: 2)(e)$ samples

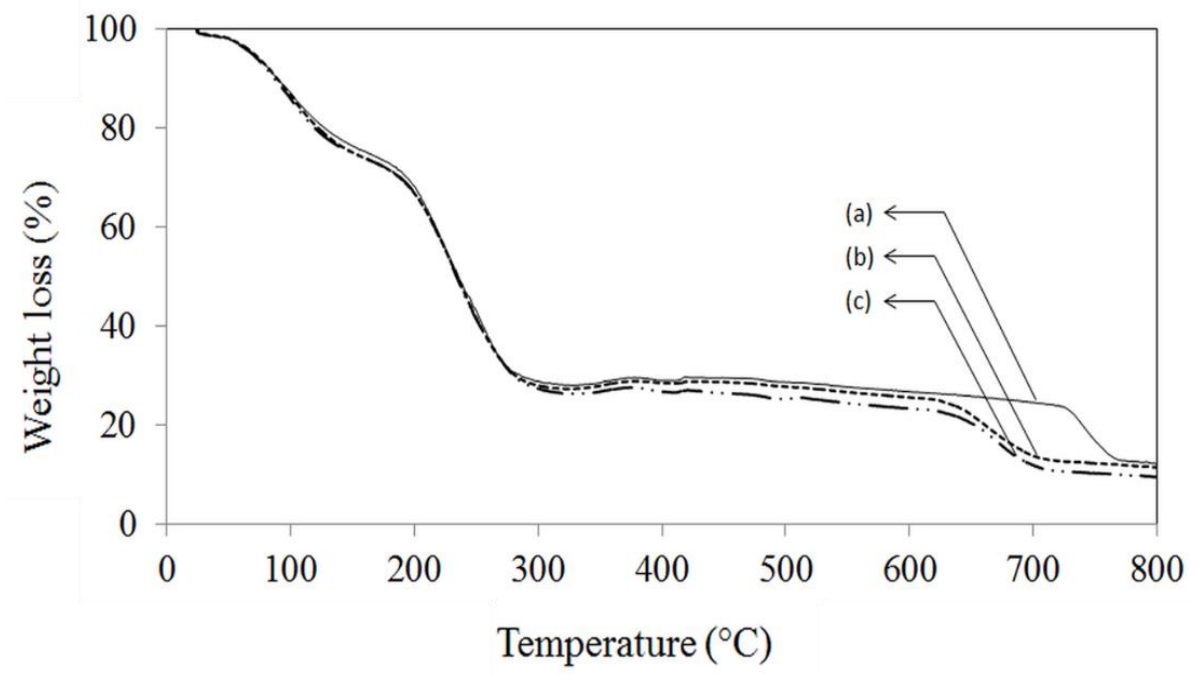

Figure 2. The TGA thermograms of TTI(3:2) (a), TTI(1:1) (b) and TTI(2:3)(c) samples 
All the samples showed a more significant mass loss in the second decomposition step. In this stage, the mass loss of pure A and PVA started at similar temperatures (about $185^{\circ} \mathrm{C}$ ) implying that the thermal stability of pure PVA and A are almost the same [21]. PVA showed a high mass loss $(57 \%)$ occurring at a temperature region of 185 to $402{ }^{\circ} \mathrm{C}$. This result is in coincidence with literature [29-31]. Ahad et al. [29] reported that the mass loss of PVA occurring in the range of 178 to $368{ }^{\circ} \mathrm{C}$ was about $45 \%$. The reason of the higher mass loss of PVA in second stage was attributed to the degradation of the side chain $(\mathrm{O}-\mathrm{H})$ and the bond scission in the polymeric backbone by some authors [29, 31-33]. Pure A and APVA blends showed similar mass loss values (34-39\%) which were lower than the mass loss (45$46 \%$ ) of TTI blends. In this step, the start of mass loss raised to higher temperatures (193$197{ }^{\circ} \mathrm{C}$ ) for APVA blends when compared to pure A or PVA which reveals that the APVA blends have higher thermal stability. Çaykara and Demirci [21] recorded that the mass loss of pure PVA and sodium alginate started at around $230{ }^{\circ} \mathrm{C}$ while that of PVA/sodium alginate blends started at higher temperatures due to some specific intermolecular interactions between them. For the TTI blends, however, the initial degradation temperature in the second step decreased below those of pure A and PVA. The mass loss which corresponds to this stage was also higher (about 45-46\%) than pure A and APVA blends. This reveals that the addition of glycerol, ascorbic acid and beet root extract to APVA blends reduced the thermal stability. The ratio of A to PVA in blend films did not create a significant effect on TGA thermograms. PVA showed approximately $11 \%$ mass loss between 410 and $497{ }^{\circ} \mathrm{C}$ which is associated with the decomposition of the main polymer chain $[29,33]$. In this stage thermal decomposition of alginate started at higher temperature $\left(568.4^{\circ} \mathrm{C}\right)$ compared to PVA. APVA and TTI blends exhibited enhancement in thermal stability. For TTI blends, the thermal degradation temperature was shifted toward higher temperatures with increasing A content. However, the percent mass loss of APVA or TTI blends did not affected by the ratio of A to PVA.

\section{FT-IR analysis}

FT-IR spectra of A, PVA, APVA and TTI blend polymer matrix studied in the range 4000-600 $\mathrm{cm}^{-1}$ were presented in Figure 3. For all films, the large bands observed in the range of $3000-3700 \mathrm{~cm}^{-1}$ are attributed stretching vibrations of $\mathrm{O}-\mathrm{H}$ from the intramolecular and intermolecular hydrogen bonds [34-36]. The FT-IR spectra of PVA shows a band between 2900-2940 $\mathrm{cm}^{-1}$ indicating the stretching C-H from alkyl groups [34, 37], a band between $1327-1421 \mathrm{~cm}^{-1}$ indicating bending and wagging of $\mathrm{CH}_{2}$ vibrations [35], a band at $1083 \mathrm{~cm}^{-}$ ${ }^{1}$, indicating C-O stretching [35, 38]. According to literature, the $1141 \mathrm{~cm}^{-1}$ band is sensitive to crystalline parts of the PVA chain [39]. In the FT-IR spectrum of alginate, the peaks at 2926, 1597, 1409 and $1300 \mathrm{~cm}^{-1}$ were assigned to aliphatic $\mathrm{C}-\mathrm{H}$ stretching, antisymmetric $\mathrm{COO}^{-}$stretching, symmetric $\mathrm{COO}^{-}$stretching and skeletal vibrations, respectively [36, 40, 41]. The sodium alginate spectrum also shows a band at $1029 \mathrm{~cm}^{-1}$ related to stretching vibration of the $\mathrm{C}-\mathrm{O}-\mathrm{C}$ bond $[36,42]$. APVA blend films display an FT-IR spectrum that is very similar to alginate. Compared to pure PVA, the $\mathrm{O}-\mathrm{H}$ stretching band of APVA blend films became wider and shifted to lower frequency which may be related with the formation of intermolecular hydrogen bonding between PVA and alginate. The intensity of $\mathrm{O}-\mathrm{H}$ stretching band clearly increased in TTI films compared to other films. In addition, the aliphatic $\mathrm{C}-\mathrm{H}$ stretching, the antisymmetric and symmetric $\mathrm{COO}^{-}$stretching and the $\mathrm{C}-\mathrm{O}-\mathrm{C}$ stretching vibration band intensities were also clearly higher in TTI films compared to alginate film. In TTI films, a band is appeared at $1716 \mathrm{~cm}^{-1}$ probably originated from stretching vibrations of $\mathrm{C}=\mathrm{C}$ bonds of ascorbic acid [43]. 

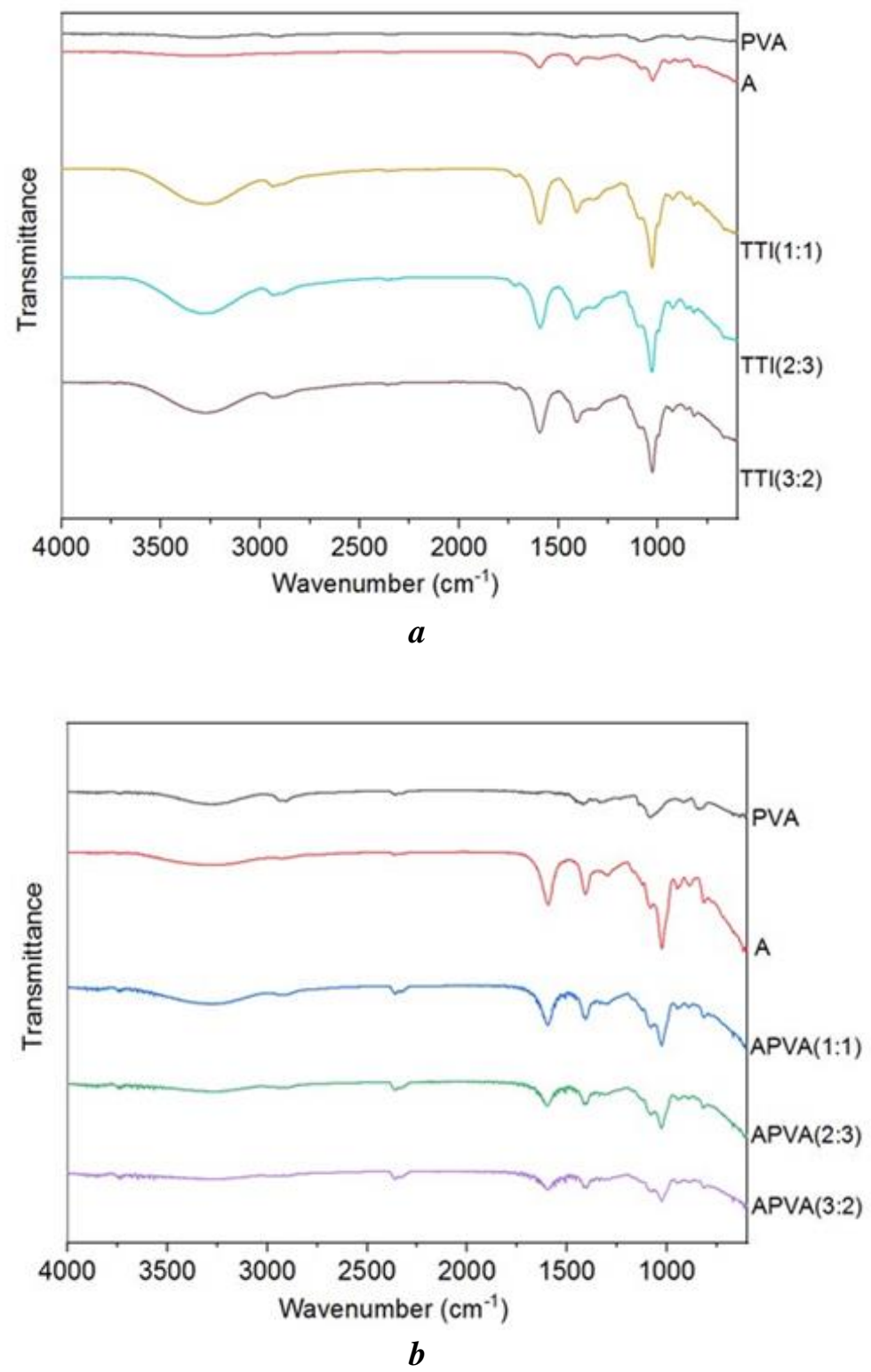

Figure 3. FTIR spectra of films

\section{SEM analysis}

The SEM micrographs of the surface and cross section of pure PVA and A films were shown in Figure 4. 


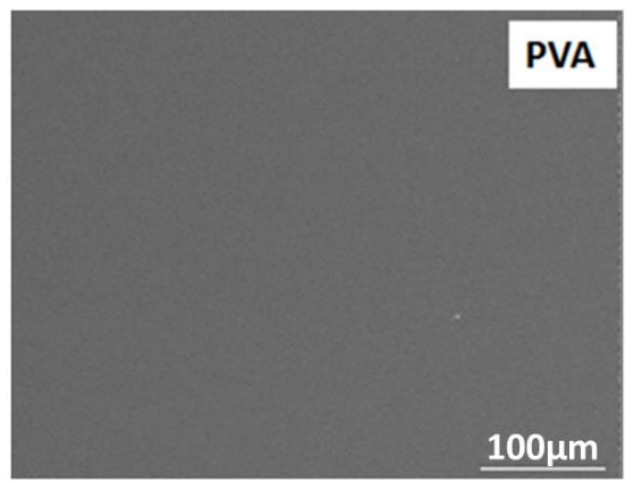

$a$

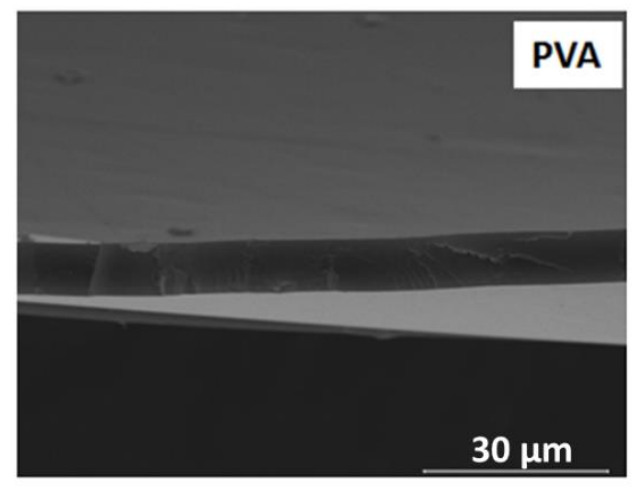

$c$

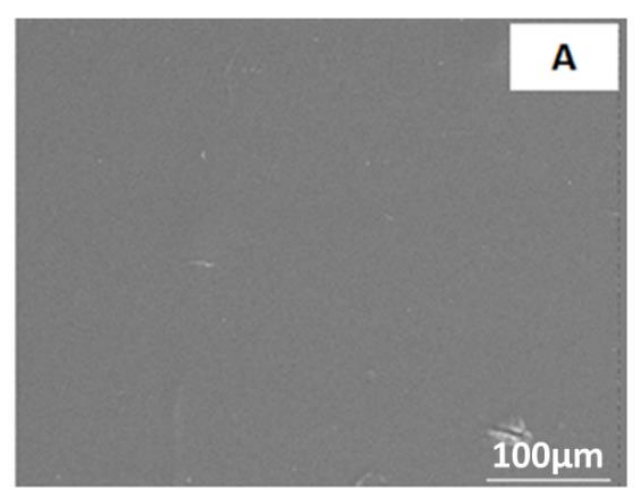

$b$

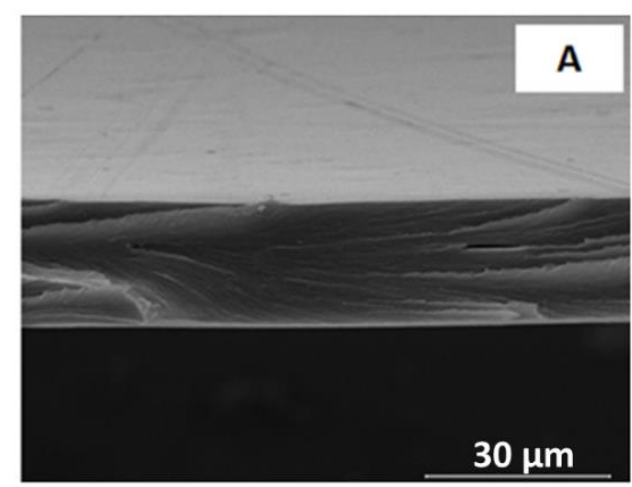

$d$

Figure 4. The surface $(250 x)(a, b)$ and the cross section $(3000 x)(c, d)$ SEM images of $A$ and PVA films

PVA and A films had smooth, homogeneous and continuous structures as seen from the figure. However, there was a uniform surface roughness observed for APVA (3:2)-G blend film (Figure 5). The surface of the film had no visible crack but had some bulges. The possible reason is that the blend film exhibited phase separation. This is also consistent with several previous studies involving PVA and alginate. Phase separation was observed in sodium alginate/PVA blend membranes by Yeom and Lee [44] and PVA-alginate ester based membranes by Amri et al. [45].

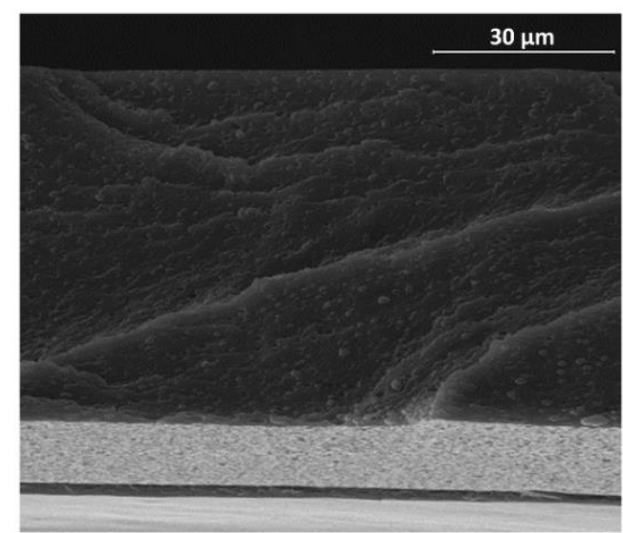

Figure 5. The SEM image of APVA(3:2)-G film (3000x) 
Figure 6 presents the SEM micrographs of the surface and cross section of TTI blend films. The appearance of the TTI films were similar to that of APVA(3:2)-G blend film. The surface of the TTI films were flat without any crack but had many small or large sized bulges. It may be observed from the figure that the phase separation is more significant in the TTI(2:3) film which contains higher amount of PVA in its formulation. Yeom and Lee [44] stated that the continuous matrix in sodium alginate/PVA blend membranes was composed mainly of sodium alginate while PVA formed the separated domains. This explains the larger size of separated domains in TTI(2:3) films. The mechanical properties of the film are affected by the uniform distribution of the polymers in the matrix. This result is consistent with the results of mechanical properties of the films. This means that the higher alginate proportion in TTI blend films decreased the phase separation and improved the handling properties of TTI film.

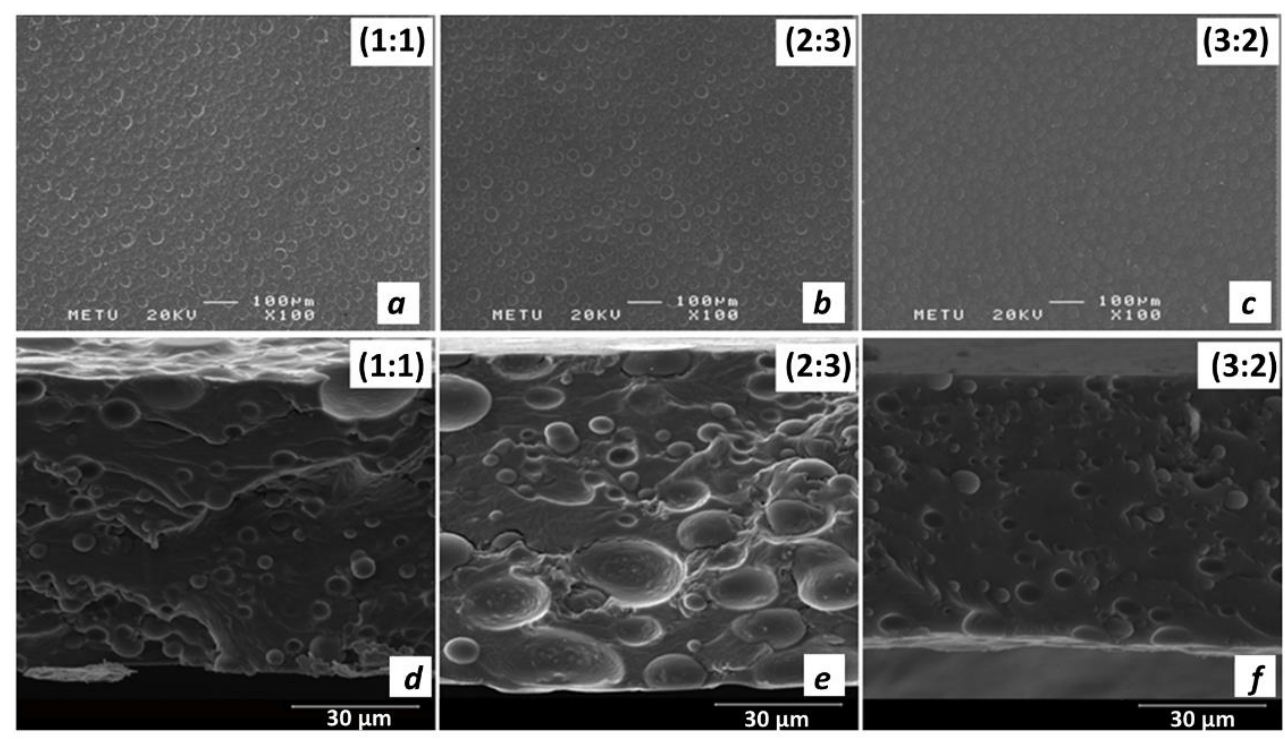

Figure 6. The surface $(100 x)(a, b, c)$ and the cross section $(3000 x)(d, e, f)$ SEM images of TTI(1:1), TTI(2:3) and TTI(3:2) films

\section{Colourimetric characterization of TTI film}

TTI film developed in this study contains water extract of red beetroot as color indicator. Red beet root extract contains a group of water-soluble pigments called betalains [18]. Betalains are classified into two major structural groups of pigments: betacyanins (red-violet) and betaxanthins (yellow-orange) [46]. The $\mathrm{pH}$ affects the colorimetric parameters of betalains and the stability of betalain pigments during storage [47]. The pH of TTI film forming solution was adjusted to 9.5 in order to be able to obtain the desired color change at the studied temperatures. The average values of the initial CIE $\mathrm{L}^{*} \mathrm{a}^{*}, \mathrm{~b}^{*}$ color parameters of the TTI film were recorded as $76.83 \pm 1.70,29.2 \pm 1.97$ and $-9.43 \pm 0.28$, respectively. The $\mathrm{L}^{*}$, $\mathrm{a}^{*}$ and $\mathrm{b}^{*}$ color parameters of TTI $(3: 2)$ film exposed to different temperatures were recorded each day for 7 days. Table 3 presents the change in $\mathrm{L}^{*}, \mathrm{a}^{*}$ and $\mathrm{b}^{*}$ color parameter of the TTI film. It was found that temperature, time and temperature $\mathrm{x}$ time interaction were all important factors affecting the color parameters of the TTI film (Table 4). The L* values of TTI films subjected to 4,25 and $40^{\circ} \mathrm{C}$ temperatures did not undergo significant changes, 
while the $\mathrm{L}^{*}$ value of the TTI film exposed to $60^{\circ} \mathrm{C}$ decreased significantly on the first day and fluctuated between 58.00 \pm 3.69 and $69.24 \pm 1.61$ throughout following days. Similar to $\mathrm{L}^{*}$, the parameter $\mathrm{a}^{*}$ (green-red axis) of TTI film remained nearly constant during seven days of storage at refrigerator temperature $\left(4^{\circ} \mathrm{C}\right)$. At other temperatures, there was a significant reduction in $\mathrm{a}^{*}$ value of TTI film at the end of seven days. The reduction in a* value was significant on the third and sixth days of storage at 25 and $40{ }^{\circ} \mathrm{C}$, respectively. At $60{ }^{\circ} \mathrm{C}$, however, significant decrease in $\mathrm{a}^{*}$ value was detected on the initial day, and then statistically insignificant reduction in consecutive days was observed until end of storage.

Table 3

Change of the $L^{*}, a^{*}$ and $b^{*}$ color parameter of TTI film exposed to different temperatures

\begin{tabular}{|c|c|c|c|c|c|}
\hline \multirow{2}{*}{$\begin{array}{c}\text { Color } \\
\text { Parameter }\end{array}$} & \multirow{2}{*}{ Day } & \multicolumn{4}{|c|}{ Temperature } \\
\hline & & $4^{\circ} \mathrm{C}$ & $25^{\circ} \mathrm{C}$ & $40^{\circ} \mathrm{C}$ & $60^{\circ} \mathrm{C}$ \\
\hline \multirow{8}{*}{$\mathrm{L}^{*}$} & 0 & $77.4^{\mathrm{a}^{*} \mathrm{~A}^{* *} \pm 0.91}$ & $78.99^{\mathrm{aA}} \pm 0.74$ & $75.40^{\mathrm{aA}} \pm 2.88$ & $75.55^{\mathrm{aA}} \pm 2.05$ \\
\hline & 1 & $76.76^{\mathrm{aA}} \pm 1.25$ & $78.66^{\mathrm{aA}} \pm 0.77$ & $74.52^{\mathrm{aA}} \pm 2.61$ & $58.00^{\mathrm{dB}} \pm 3.69$ \\
\hline & 2 & $78.47^{\mathrm{aA}} \pm 1.77$ & $79.26^{\mathrm{aA}} \pm 1.04$ & $75.70^{\mathrm{aA}} \pm 2.33$ & $56.93^{\mathrm{dB}} \pm 3.70$ \\
\hline & 3 & $76.53^{\mathrm{aA}} \pm 0.48$ & $78.36^{\mathrm{aA}} \pm 0.52$ & $73.37^{\mathrm{aA}} \pm 4.70$ & $61.84^{\mathrm{cdB}} \pm 2.61$ \\
\hline & 4 & $76.46^{\mathrm{aA}} \pm 0.33$ & $78.49^{\mathrm{aA}} \pm 1.31$ & $68.18^{\mathrm{aB}} \pm 4.61$ & $66.45^{\mathrm{bcB}} \pm 0.22$ \\
\hline & 5 & $76.83^{\mathrm{aA}} \pm 1.60$ & $79.94^{\mathrm{aA}} \pm 0.58$ & $75.10^{\mathrm{aA}} \pm 2.27$ & $66.53^{\mathrm{bcB}} \pm 0.18$ \\
\hline & 6 & $77.17^{\mathrm{aAB}} \pm 0.29$ & $79.47^{\mathrm{aA}} \pm 0.29$ & $73.34^{\mathrm{aB}} \pm 3.86$ & $64.34^{\mathrm{bcc}} \pm 1.70$ \\
\hline & 7 & $76.60^{\mathrm{aA}} \pm 0.53$ & $79.17^{\mathrm{aA}} \pm 0.31$ & $73.57^{\mathrm{aB}} \pm 2.16$ & $69.24^{\mathrm{bC}} \pm 1.60$ \\
\hline \multirow{8}{*}{$a^{*}$} & 0 & $28.77^{\mathrm{aA}} \pm 0.11$ & $26.76^{\mathrm{aA}} \pm 0.48$ & $30.67^{\mathrm{aA}} \pm 3.80$ & $30.71^{\mathrm{aA}} \pm 2.82$ \\
\hline & 1 & $29.02^{\mathrm{aA}} \pm 1.08$ & $26.94^{\mathrm{aA}} \pm 0.85$ & $29.98^{\mathrm{abA}} \pm 3.26$ & $21.92^{\mathrm{bB}} \pm 0.90$ \\
\hline & 2 & $28.31^{\mathrm{aA}} \pm 1.39$ & $26.28^{\mathrm{abA}} \pm 0.82$ & $28.10^{\mathrm{abcA}} \pm 2.42$ & $20.97^{\mathrm{bB}} \pm 0.89$ \\
\hline & 3 & $28.81^{\mathrm{aA}} \pm 0.49$ & $24.82^{\mathrm{bcA}} \pm 0.56$ & $26.30^{\mathrm{abcA}} \pm 4.00$ & $19.81^{\mathrm{bcB}} \pm 0.28$ \\
\hline & 4 & $28.88^{\mathrm{aA}} \pm 0.55$ & $24.08^{\mathrm{cdB}} \pm 0.87$ & $25.83^{\mathrm{abcB}} \pm 1.67$ & $20.30^{\mathrm{bcC}} \pm 0.93$ \\
\hline & 5 & $28.89^{\mathrm{aA}} \pm 0.80$ & $23.11^{\mathrm{deB}} \pm 0.69$ & $24.36^{\mathrm{abcB}} \pm 2.00$ & $20.23^{\mathrm{bcC}} \pm 0.27$ \\
\hline & 6 & $28.66^{\mathrm{aA}} \pm 0.36$ & $22.27^{\mathrm{deB}} \pm 0.20$ & $23.90^{\mathrm{bcB}} \pm 2.93$ & $18.78^{\mathrm{bcc}_{ \pm}} \pm .53$ \\
\hline & 7 & $28.20^{\mathrm{aA}} \pm 0.42$ & $22.26^{\mathrm{eB}} \pm 0.25$ & $22.61^{\mathrm{cB}} \pm 0.25$ & $16.09^{\mathrm{cC}} \pm 0.53$ \\
\hline \multirow{8}{*}{$b^{*}$} & 0 & $-9.72^{\mathrm{aA}} \pm 0.18$ & $-9.64^{\mathrm{aA}} \pm 0.05$ & $-9.23^{\mathrm{aA}} \pm 0.17$ & $-9.14^{\mathrm{aA}} \pm 0.12$ \\
\hline & 1 & $-9.703^{\mathrm{aA}} \pm 0.20$ & $-8.49^{\mathrm{bB}} \pm 0.25$ & $-5.02^{\mathrm{cC}} \pm 0.40$ & $0.06^{\mathrm{bD} \pm 0.01}$ \\
\hline & 2 & $-9.66^{\mathrm{abA}} \pm 0.10$ & $-6.71^{\mathrm{cB}} \pm 0.44$ & $-0.86^{\mathrm{cC}} \pm 0.68$ & $3.84^{\mathrm{cD}} \pm 0.39$ \\
\hline & 3 & $-9.57^{\mathrm{bcA}} \pm 0.10$ & $-4.52^{\mathrm{dB}} \pm 0.25$ & $3.10^{\mathrm{dC}} \pm 2.20$ & $6.15^{\mathrm{cdD}} \pm 0.14$ \\
\hline & 4 & $-9.47^{\mathrm{bcA}} \pm 0.03$ & $-3.85^{\mathrm{dB}} \pm 0.21$ & $4.10^{\mathrm{dC}} \pm 1.21$ & $7.06^{\mathrm{dD}_{ \pm} 0.06}$ \\
\hline & 5 & $-9.19^{\mathrm{cA}} \pm 0.24$ & $-2.12^{\mathrm{eB}} \pm 0.13$ & $5.38^{\mathrm{dC}} \pm 1.75$ & $8.00^{\mathrm{eD}} \pm 0.22$ \\
\hline & 6 & $-9.03^{\mathrm{cA}} \pm 0.29$ & $0.29^{\mathrm{fB}} \pm 0.11$ & $6.16^{\mathrm{dC} \pm 2.65}$ & $9.73^{\mathrm{fD}} \pm 1.16$ \\
\hline & 7 & $-9.00^{\mathrm{cA}} \pm 0.03$ & $1.28^{\mathrm{gB}} \pm 0.58$ & $6.77^{\mathrm{dC}} \pm 2.28$ & $12.59^{\mathrm{gD}} \pm 0.72$ \\
\hline \multirow{8}{*}{ Hue angle } & 0 & $341.32^{\mathrm{abA}} \pm 0.32$ & $340.18^{\mathrm{gA}} \pm 0.39$ & $343.93^{\mathrm{fA}} \pm 0.78$ & $343.048^{\mathrm{gA}} \pm 1.16$ \\
\hline & 1 & $341.49^{\mathrm{abC}} \pm 0.93$ & $342.49^{\mathrm{fC}} \pm 0.78$ & $351.23^{\mathrm{e}} \pm 0.35$ & $359.011^{\mathrm{fA}} \pm 1.47$ \\
\hline & 2 & $341.11^{\mathrm{bD}} \pm 1.01$ & $345.64^{\mathrm{eC}^{\mathrm{C}}} \pm 1.26$ & $358.15^{\mathrm{dB}} \pm 1.63$ & $10.36^{\mathrm{eA}} \pm 0.63$ \\
\hline & 3 & $341.61^{\mathrm{abD}} \pm 0.29$ & $349.65^{\mathrm{dC}} \pm 0.79$ & $8.08^{\mathrm{cB}} \pm 1.97$ & $17.25^{\mathrm{dA}} \pm 0.61$ \\
\hline & 4 & $341.84^{\mathrm{abD}_{ \pm}} \pm .37$ & $350.89^{\mathrm{dC}^{\mathrm{C}}} \pm 0.83$ & $8.04^{\mathrm{CB}} \pm 1.28$ & $19.22^{\mathrm{cdA}} \pm 0.72$ \\
\hline & 5 & $342.34^{\mathrm{abD}} \pm 0.55$ & $354.74^{\mathrm{cC}} \pm 0.47$ & $13.51^{\mathrm{bB}} \pm 2.07$ & $21.59^{\mathrm{cA}} \pm 0.53$ \\
\hline & 6 & $342.50^{\mathrm{aD}} \pm 0.46$ & $0.75^{\mathrm{bC}} \pm 0.20$ & $18.130^{\mathrm{abB}} \pm 2.90$ & $27.35^{\mathrm{bA}} \pm 2.69$ \\
\hline & 7 & $342.28^{\mathrm{abD}} \pm 0.31$ & $1.30^{\mathrm{aC}} \pm 0.28$ & $21.28^{\mathrm{aB}} \pm 0.17$ & $35.27^{\mathrm{aA}} \pm 1.55$ \\
\hline
\end{tabular}

*Data are expressed as mean \pm standard deviation. For each color parameter, means with different lower case letters $(a, b, c)$ in the same column are significantly different at $p \leq 0.05$.

** For each color parameter, means with different capital letters (A, B, C) in the same row are significantly different at $\mathrm{p} \leq 0.05$ 
The parameter $b^{*}$ (blue-yellow axis) underwent more distinct changes compared to parameters $a^{*}$ and $L^{*}$. At refrigerator temperature, $b^{*}$ value of TTI film increased from the initial value of -9.72 to -9.57 after three days. This increase was found to be statistically significant. The $b^{*}$ value remained statistically stable in consecutive days and reached to 9.00 at the end of seventh day. At the other temperatures, significant increases in $b^{*}$ values of TTI films were detected on the initial day. At the end of seventh day, the $b^{*}$ values of the samples subjected to temperatures of 25,40 and $60{ }^{\circ} \mathrm{C}$ were $1.28,6.77$ and 12.59, respectively. The effect of temperature on the $b^{*}$ values of the TTI film was statistically significant from the first day. The highest change in the $b^{*}$ value occurred in the film kept at $60{ }^{\circ} \mathrm{C}$. The hue angle is expressed in positive degrees ranging from 0 to 360 . The angle of $0^{\circ}$ or $360^{\circ}$ indicates red color while the angles of $90^{\circ}, 180^{\circ}$ and $270^{\circ}$ represent yellow, green and blue colors, respectively. Initially, the TTI film had an average hue value of 342.12. The change in hue value was not significant during 7 days at $4{ }^{\circ} \mathrm{C}$, while significant change was observed from the first day at other temperatures. The hue angle changed in the counterclockwise direction and rapidly passed the red color axis $\left(0^{\circ}\right)$ at 40 and $60{ }^{\circ} \mathrm{C}$.

Table 4

ANOVA showing the effects of temperature (T), storage time ( $(t)$, and interaction term $(\mathbf{T} \times \mathrm{t})$ on color values

\begin{tabular}{|c|c|c|c|c|c|c|c|c|}
\hline \multirow[t]{2}{*}{ Source } & \multicolumn{2}{|c|}{$\mathbf{L}^{*}\left(\mathbf{R}^{2}{ }_{\text {adj }}=0.89\right)$} & \multicolumn{2}{|c|}{$\mathbf{a}^{*}\left(\mathbf{R}^{2}{ }^{2} \mathbf{c}=0.82\right)$} & \multicolumn{2}{|c|}{$b^{*}\left(\mathbf{R}^{2}{ }_{\text {adj }}=0.98\right)$} & \multicolumn{2}{|c|}{$\operatorname{Hue}\left(R_{\text {adj }}^{2}=0.98\right)$} \\
\hline & $\begin{array}{l}\text { Adj } \\
\text { MS }\end{array}$ & Pvalue & $\begin{array}{l}\text { Adj } \\
\text { MS }\end{array}$ & Pvalue & $\begin{array}{l}\text { Adj } \\
\text { MS }\end{array}$ & Pvalue & $\begin{array}{l}\text { Adj } \\
\text { MS }\end{array}$ & Pvalue \\
\hline $\mathrm{t}$ & 41.04 & 0.00 & 74.49 & 0.00 & 275.16 & 0.00 & 1399.73 & 0.00 \\
\hline $\mathrm{T}$ & 1268.51 & 0.00 & 330.15 & 0.00 & 1242.57 & 0.00 & 6653.93 & 0.00 \\
\hline $\mathrm{T} \times \mathrm{t}$ & 42.01 & 0.00 & 15.38 & 0.00 & 37.08 & 0.00 & 212.85 & 0.00 \\
\hline Error & 4.56 & & 3.03 & & 0.83 & & 5.50 & \\
\hline
\end{tabular}

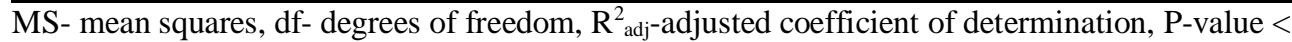
0.05 denotes significant effect

Higher temperatures accelerated the color change of TTI film as seen in Figure 7. The color of the film exposed to $60^{\circ} \mathrm{C}$ changed considerably on the first day. The color change at temperatures 40 and $60^{\circ} \mathrm{C}$ was visually appreciable by human eyes on the first day. Maciel et al. [15] developed a colourimetric temperature indicator by covering the surface of a card paper with chitosan matrix film containing anthocyanin. The indicator was exposed to temperatures of 20,40 and $60{ }^{\circ} \mathrm{C}$ with or without luminosity ( 0 or $1000 \mathrm{~lx}$ ) for 72 hours. They recorded no significant change in $\mathrm{a}^{*}$ value irrespective of temperature and luminosity. Similar to our findings, they observed the most significant change in $b^{*}$ parameter and the highest change in $b^{*}$ value was obtained at $60{ }^{\circ} \mathrm{C}$. They stated that the color of the indicator changed from light purple to slightly yellow which is associated with the alteration in anthocyanin structure. It is known that the pigment structure and concentration, temperature, $\mathrm{pH}$, oxygen, light, water activity, metal cations, antioxidants and enzymes are among the factors affecting the stability of betalain pigments [18, 48]. Herbach et al. [49] stated that the degradation rate of betalains increases with increasing temperature which results chromatic changes depending on several degradation and transformation reactions. Herbach et al. [50] reported that thermal treatment of betacyanin solution caused increasing hue angle values. 
The yellow compounds formed as a result of degradation reactions like hydrolysis or dehydrogenation may be responsible for the increased $b^{*}$ value of the films [49].

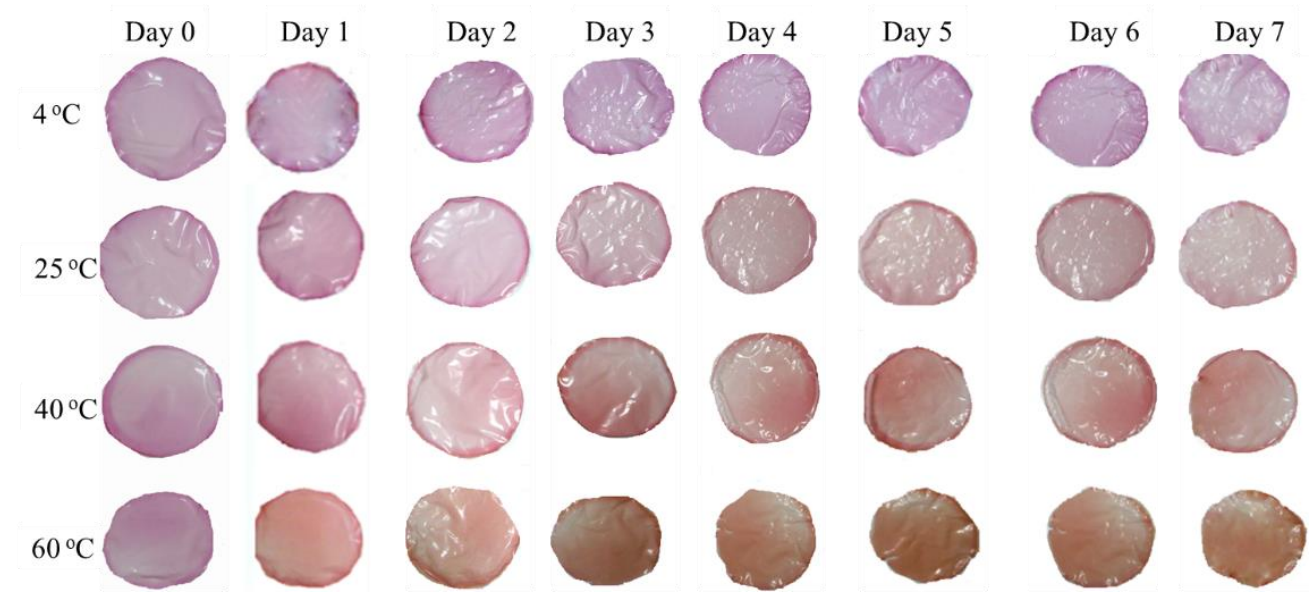

Figure 7. Color images of the TTI films stored at 4, 25, 40 and $60{ }^{\circ} \mathrm{C}$ during 7 days

\section{Conclusion}

Time temperature indicators applied to intelligent packaging are low-cost and userfriendly systems informing consumers about quality and safety of food. In this study, TTI films were prepared by adding red beet root extract to blend films with different ratio of alginate and PVA. The analysis showed that TTI film made up of A and PVA with a ratio of (3:2) provided enhancement of the mechanical properties and reduction of the phase separation observed in SEM images. The color change of this film was investigated at different temperatures. A visual color change was observed in the film upon exposure to temperatures of 25,40 and $60{ }^{\circ} \mathrm{C}$ while it maintained its color for 7 days at refrigerator temperature. Results indicated that, this indicator may have potential applications to monitor food products requiring refrigeration.

Acknowledgements. This work was supported by a grant from Ordu University (TF 1528)

\section{References}

1. Marsh K., Bugusu B. (2007), Food packaging-roles, materials, and environmental issues, Journal of Food Science, 72(3), pp. R39-R55.

2. Wyrwa J., Barska A. (2017), Innovations in the food packaging market: active packaging, European Food Research and Technology, 243, pp. 1681-1692.

3. Biji K.B., Ravishankar C.N., Mohan C.O., Srinivasa Gopal T.K. (2015), Smart packaging systems for food applications: a review, Journal of Food Science and Technology, 52(10), pp. 6125-6135. 
4. Janjarasskul T., Suppakul P. (2018), Active and intelligent packaging: The indication of quality and safety, Critical Reviews in Food Science and Nutrition, 58 (5), pp. 808-831.

5. Yam K.L., Takhistov P.T., Miltz J. (2005), Intelligent packaging: concepts and applications, Journal of Food Science, 70(1), pp. R1-R10.

6. Day B.P.E. (2008), In: Kerry J., Butler P. (eds), Smart packaging technologies for fast moving consumer goods, John Wiley, Chichester.

7. Wang S.D., Liu X.H., Yang M., Zhang Y., Xiang K.Y., Tang R. (2015), Review of time temperature indicators as quality monitors in food packaging, Packaging Technology and Science, 28(10), pp. 839-867.

8. Kim M.J., Jung S.W., Park H.R., Lee S.J. (2012), Selection of an optimum pH indicator for developing lactic acid bacteria-based time temperature integrators (TTI), Journal of Food Engineering, 113(3), pp. 471-478.

9. Pennanen K., Focas C., Kumpusalo-Sanna V., Keskitalo-Vuokko K., Matullat I., et al. (2016), European consumers' perceptions of time-temperature indicators in food packaging. Packaging Technology and Science, 29(4), pp. 610-610.

10. Shukla V., Kandeepan G., Vishnuraj M.R., Soni A. (2016), Anthocyanins based indicator sensor for intelligent packaging application, Agricultural Research, 5, pp. 205-209.

11. Musso Y.S., Salgado P.R., Mauri A.N. (2019), Smart gelatin films prepared using red cabbage (Brassica oleracea L.) extracts as solvent, Food Hydrocolloids, 89, pp. 674681.

12. Silva-Pereira M.C., Teixeira J.A., Pereira-Junior V.A., Stefani R. (2015), Chitosan/corn starch blend films with extract from Brassica oleraceae (red cabbage) as a visual indicator of fish deterioration, LWT Food Science and Technology, 61(1), pp. 258-262.

13. Mohebi E., Marquez L. (2015), Intelligent packaging in meat industry: An overview of existing solutions, Journal of Food Science and Technology, 52(7), pp. 3947-3964.

14. Nofrida R., Warsiki E., Yuliasih I. (2013), The effect of storage temperature on the erpa leaf (Aerva sanguinolenta) color indicator smart label, Jurnal Teknologi Industri Pertanian, 23 (3), pp. 232-241.

15. Maciel V.B.V., Yoshida C.M.P., Franco T.T. (2012), Development of a prototype of a colourimetric temperature indicator for monitoring food quality, Journal of Food Engineering, 111(1), pp. 21-27.

16. Maciel V.B.V., Yoshida C.M.P., Franco T.T. (2014), Development of temperature indicator prototype: Cardpaper coated with chitosan intelligent films, Journal of Agricultural Chemistry and Environment, 3(1), pp. 5-10.

17. Pedreno M.A., Escribano J. (2001), Correlation between antiradical activity and stability of betanine from Beta vulgaris $\mathrm{L}$ roots under different $\mathrm{pH}$, temperature and light conditions, Journal of the Science of Food and Agriculture, 81(7), pp. 627-631.

18. Azeredo H.M.C. (2009), Betalains: properties, sources, applications and stability - a review, International Journal of Food Science and Technology, 44(12), pp. 2365-2376.

19. Drdak K.M., Vallova M. (1990), Kinetics of the thermal degradation of betanine, Die Nahrung, 34(4), pp. 307-310.

20. Pereira V.A., de Arruda I.N.Q., Stefani R. (2015), Active chitosan/PVA films with anthocyanins from Brassica oleraceae (red cabbage) as time temperature indicators for application in intelligent food packaging, Food Hydrocolloids, 43, pp. 180-188.

21. Çaykara T., Demirci S. (2006), Preparation and characterization of blend films of poly(vinylalcohol) and sodium alginate, Journal of Macromolecular Science Part A Pure and Applied Chemistry, 43(7), pp. 1113-1121. 
22. Senturk Parreidt T., Muller K., Schmid M. (2018), Alginate-based edible films and coatings for food packaging applications, Foods, 7(10), pp. 170.

23. Russo R.A., Giuliani B., Immirzi M., Malinconico M., Romano G. (2004), Alginate/polyvinylalcohol blends for agricultural applications: structure-properties correlation, mechanical properties and greenhouse effect evaluation, Macromolecular Symposia, 218, pp. 241-250.

24. ASTM D618-61 (1993) Standard practice for conditioning plastics and electrical insulating materials for testing.

25. ASTM D1708-10 (2010) Standard test method for tensile properties of plastics by use of microtensile specimen.

26. McLellan M.R., Lind L.R., Kime R.W. (1995), Hue angle determinations and statistical analysis for multiquadrant hunter L,a,b data, Journal of Food Quality, 18(3), pp. 235240.

27. Kadhim M.M., Shakheer A.I., Fahim A.H., A kadhim M.M.H. (2018), Effect of type and concentration of plasticizer on mechanical properties of protein edible films, International Journal of Mechanical Engineering and Technology, 9(10), pp. 14931503.

28. Sanyang M.L., Sapuan S.M., Jawaid M., Ishak M.R., Sahari J. (2015), Effect of plasticizer type and concentration on tensile, thermal and barrier properties of biodegradable films based on sugar palm (Arenga pinnata) starch, Polymers, 7(6), pp. 1106-1124.

29. Ahad N., Saion E., Gharibshahi E. (2012), Structural, thermal, and electrical properties of PVA-sodium salicylate solid composite polymer electrolyte, Journal of Nanomaterials, DOI: 10.1155/2012/857569.

30. Anbarasan R., Pandiarajaguru R., Prabhu R., Dhanalakshmi V., Jayalakshmi A., Dhanalakshmi B., Nisha S.U., Gandhi S., Jayalakshmi T. (2010), Synthesis, characterizations, and mechanical properties of structurally modified poly(vinyl alcohol), Journal of Applied Polymer Science, 117(4), pp. 2059-2068.

31. Guirguis O.W., Moselhey M.T.H. (2012), Thermal and structural studies of poly(vinyl alcohol) and hydroxypropyl cellulose blends, Natural Science, 4(1), pp. 57-67.

32. Pawar R.P. (2015), Study of thermal decomposition and instrumental analysis of synthesised polyvinyl alcohol polymer, Journal of Ultra Chemistry, 11(1), pp. 1-6.

33. Pirzada T., Shah S.S. (2014), Water-resistant poly(vinyl alcohol)-silica hybrids through sol-gel processing, Chemical Engineering Technology, 37(4), pp. 620-626.

34. Mansur H.S., Sadahira C.M., Souza A.N., Mansur A.A.P. (2008), FTIR spectroscopy characterization of poly(vinyl alcohol) hydrogel with different hydrolysis degree and chemically crosslinked with glutaraldehyde, Materials Science and Engineering, 28(4), pp. 539-548.

35. Kumar K.N., Padma R., Rao J.L., Kang M. (2016), Dazzling green emission from graphene oxide nanosheet-embedded co-doped Ce3+ and Tb3+:PVA polymer nanocomposites for photonic applications, The Royal Society of Chemistry Advances, 6(59), pp. 54525- 54538.

36. Lawrie G., Keen I., Drew B., Chandler-Temple A., Rintoul L., Fredericks P., Grøndahl L. (2007), Interactions between alginate and chitosan biopolymers characterized using FTIR and XPS, Biomacromolecules, 8, pp. 2533-2541.

37. Awada H., Daneault C. (2015), Chemical modification of poly(vinyl alcohol) in water, Applied Science, 5, pp. 840-850. 
38. Pawde S.M., Deshmukh K. (2008), Characterization of polyvinyl alcohol/gelatin blend hydrogel films for biomedical applications, Journal of Applied Polymer Science, 109, pp. 3431-3437.

39. Peppas N.A. (1977), Infrared spectroscopy of semicrystalline poly(viny1 alcohol) networks, Macromolecular Chemistry and Physics, 178(2), pp. 595-601. ,

40. Çaykara T., Demirci S., Eroğlu M., Güven O. (2005), Poly (ethylene oxide) and its blends with sodium alginate, Polymer, 46(24), pp. 10750-10757.

41. Xiao Q., Gu X., Tan S. (2014), Drying process of sodium alginate films studied by twodimensional correlation ATR-FTIR spectroscopy, Food Chemistry, 164, pp.179-184.

42. Gao C., Pollet E., Averous L. (2017), Properties of glycerol-plasticized alginate films obtained by thermomechanical mixing, Food Hydrocolloids, 63, pp. 414-420.

43. Zhang Z.H., Zeng X.A., Brennan C., Brennan M., Han Z., Xiong X.Y. (2015), Effects of pulsed electric fields (PEF) on vitamin $\mathrm{C}$ and its antioxidant properties, International Journal of Molecular Sciences, 16(10), pp. 24159-24173.

44. Yeom C.K., Lee K.H. (1998), Characterization of sodium alginate and poly(vinyl alcohol) blend membranes in pervaporation separation, Journal of Applied Polymer Science, 67(5), pp. 949-959.

45. Amri C., Mudasir M., Siswanta D., Roto R. (2016), In vitro hemocompatibility of PVAalginate ester as a candidate for hemodialysis membrane, International Journal of Biological Macromolecules, 82, pp. 48-53.

46. Delgado-Vargas F., Jimenez A.R., Paredes-Lopez O. (2000), Natural pigments: Carotenoids, anthocyanins, and betalains - characteristics, biosynthesis, processing, and stability, Critical Reviews in Food Science and Nutrition, 40(3), pp. 173-289.

47. Cejudo-Bastante M.J., Hurtado N., Delgado A., Heredia F.J. (2016), Impact of pH and temperature on the colour and betalain content of Colombian yellow pitaya peel (Selenicereus megalanthus), Journal of Food Science and Technology, 53(5), pp. 24052413.

48. Belhadj Slimen I., Najar T., Abderrabba M. (2017), Chemical and antioxidant properties of betalains, Journal of Agricultural and Food Chemistry, 65(4), pp. 675-689.

49. Herbach K.M., Stintzing, F.C., Carle R. (2006), Betalain stability and degradationstructural and chromatic aspects, Journal of Food Science, 71 (4), pp.41-50.

50. Herbach K.M., Stintzing F.C., Carle R. (2006), Stability and color changes of thermally treated betanin, phyllocactin, and hylocerenin solutions, Journal Agricultural and Food Chemistry, 54(2), pp. 390-8.

51. Posudin Y.I., Peiris K.S., Kays S.J. (2015), Non-destructive detection of food adulteration to guarantee human health and safety, Ukrainian Food Journal, 4(2), pp. 207-260. 